\title{
Non-contiguous finished genome sequence and description of the gliding bacterium Flavobacterium seoulense sp. nov.
}

\author{
Su-Kyoung Shin ${ }^{1}$, Heemoon Goo ${ }^{2}$, Yong-Joon $\mathrm{Cho}^{3}$, Soonsung Kwon ${ }^{4}$, Dongeun Yong ${ }^{4}$ and Hana Yi ${ }^{1,2,5^{*}}$
}

\begin{abstract}
Flavobacterium seoulense strain EM1321 ${ }^{\top}$ is the type strain of Flavobacterium seoulense sp. nov., a proposed novel species within the genus Flavobacterium. This strain is a Gram-reaction-negative, aerobic, rod-shaped bacterium isolated from stream water in Bukhansan National Park, Seoul. This organism is motile by gliding. Here, we describe the features of Flavobacterium seoulense EM1321 ${ }^{\top}$, together with its genome sequence and annotation. The genome comprised 3,792,640 bp, with 3,230 protein-coding genes and 52 RNA genes.
\end{abstract}

Keywords: Flavobacterium, Gliding motility, Aerobic, Flavobacteriaceae

\section{Introduction}

Flavobacterium is the type genus of the family Flavobacteriaceae in the phylum Bacteroidetes. Flavobacterium was proposed by Bergey et al. [1,2] and the description was emended by Bernardet et al. [3]. Flavobacterium species have been isolated from various environments, including seawater, freshwater, river sediments, and soil [4-8]. Members of the genus Flavobacterium are Gramnegative, rod-shaped, yellow-pigmented, aerobic bacteria. At the time of writing, about 118 Flavobacterium species with validly published names have been described [9]; however, the genomes of only 14 type strains in this genus have been sequenced.

Flavobacterium seoulense sp. nov. strain $\mathrm{EM}_{1321^{\mathrm{T}}}(=$ KACC $18114^{\mathrm{T}}=\mathrm{JCM} 30145^{\mathrm{T}}$ ) was isolated from stream water in Bukhansan National Park, Seoul, Korea. Here, we present a summary classification and the features of Flavobacterium seoulense EM1321 ${ }^{\mathrm{T}}$ as well as its genome sequence and annotation.

\footnotetext{
* Correspondence: hanayi@korea.ac.kr

'Department of Public Health Sciences, BK21PLUS Program in Embodiment: Health-Society Interaction, Graduate School, Korea University, Seoul, Republic of Korea

${ }^{2}$ School of Biosystem and Biomedical Science, Korea University, Seoul, Republic of Korea

Full list of author information is available at the end of the article
}

\section{Classification and features}

Based on its 16S rRNA gene phylogeny and phenotypic characteristics, strain EM1321 ${ }^{\mathrm{T}}$ was classified as a member of the genus Flavobacterium (Table 1). Preliminary sequence-based identification using the 16S RNA gene sequences in the EzTaxon database [10] indicated that strain EM1321 ${ }^{\mathrm{T}}$ was most closely related to F. granuli $\mathrm{Kw} 05^{\mathrm{T}}$ (GenBank accession no. AB180738) with a sequence similarity of $96.54 \%$. This value was lower than the $98.7 \% 16 \mathrm{~S}$ rRNA gene sequence similarity as a threshold recommended by Stackebrandtia and Ebers [11] to delineate a new species without carrying out DNA-DNA hybridization. Subsequent phylogenetic analysis was performed using the 16S rRNA gene sequences of strain EM1321 ${ }^{\mathrm{T}}$ and related species. Sequences were aligned according to the bacterial rRNA secondary structure model using the jPHYDIT [12]. Phylogenic trees were constructed using neighbor-joining (NJ) and maximum-likelihood (ML) methods implemented in MEGA version 5 [13]. The resultant tree topologies were evaluated by bootstrap analyses with 1,000 random samplings. Strain EM1321 ${ }^{\mathrm{T}}$ formed a monophyletic clade together with Flavobacterium soli [5] in both the NJ and ML trees; however, the clustering was not supported by the bootstrap analysis (Figure 1). Flavobacterium nitratireducens [8] was further recovered as a sister group of the monophyletic clade in the ML tree only. Based on these phylogenetic trees, F. soli KACC $17417^{\mathrm{T}}$ and F. nitratiredu- 


\begin{tabular}{|c|c|c|c|}
\hline MIGS ID & Property & Term & Evidence code \\
\hline & Current classification & Domain Bacteria & TAS [15] \\
\hline & & Phylum Bacteroidetes & $\operatorname{TAS}[16,17]$ \\
\hline & & Order Flavobacteriales & $\operatorname{TAS}[17,18]$ \\
\hline & & Family Flavobacteriaceae & TAS $[3,19-21]$ \\
\hline & & Genus Flavobacterium & TAS $[1-3,22]$ \\
\hline & & Species F. seoulense & IDA \\
\hline & & Strain EM1321 ${ }^{\top}$ & IDA \\
\hline & Gram stain & Negative & IDA \\
\hline & Cell shape & Rod-shaped & IDA \\
\hline & Motility & Gliding & IDA \\
\hline & Sporulation & Non-sporulating & IDA \\
\hline & Temperature range & $4-35^{\circ} \mathrm{C}$ & IDA \\
\hline & Optimum temperature & $30^{\circ} \mathrm{C}$ & IDA \\
\hline MIGS-6 & Habitat & Freshwater & IDA \\
\hline MIGS-6.3 & Salinity & $0-4 \%$ & IDA \\
\hline \multirow[t]{2}{*}{ MIGS-22 } & Oxygen requirement & Aerobic & IDA \\
\hline & Carbon source & d-glucose, I-arabinose & IDA \\
\hline MIGS-15 & Biotic relationship & Free-living & IDA \\
\hline MIGS-14 & Pathogenicity & Non-pathogenic & NAS \\
\hline MIGS-4 & Geographic location & Seoul, South Korea & IDA \\
\hline MIGS-5 & Sample collection time & September 2013 & IDA \\
\hline MIGS-4.1 & Latitude & $37^{\circ} 36^{\prime} 52^{\prime \prime} \mathrm{N}$ & IDA \\
\hline \multirow[t]{2}{*}{ MIGS-4.2 } & Longitude & $126^{\circ} 59^{\prime} 19^{\prime \prime} \mathrm{E}$ & IDA \\
\hline & Isolation & Stream water & IDA \\
\hline
\end{tabular}

Evidence codes - IDA: Inferred from Direct Assay; TAS: Traceable Author Statement (i.e., a direct report exists in the literature); NAS: Non-traceable Author Statement (i.e., not directly observed for the living, isolated sample, but based on a generally accepted property for the species, or anecdotal evidence). These evidence codes are from the Gene Ontology project [23]. If the evidence is IDA, the property was directly observed by one of the authors.

cens JCM $17678^{\mathrm{T}}$ were selected as reference strains and were obtained from the corresponding culture collections for comparative study.

Strain EM1321 ${ }^{\mathrm{T}}$ was Gram-reaction negative. Cells of strain EM1321 ${ }^{\mathrm{T}}$ were rod shaped with rounded ends and motile by gliding. The cells were $1.0-1.5 \mu \mathrm{m} \times 0.3-$ $0.5 \mu \mathrm{m}$ in size (Figure 2). No flagellum was observed. The colonies were yellow in color and translucent on R2A agar medium. Growth occurred aerobically at $4-35^{\circ} \mathrm{C}$, and optimal growth was observed at $30^{\circ} \mathrm{C}$. The cells grew in $0-4 \%(\mathrm{w} / \mathrm{v}) \mathrm{NaCl}$. Strain $\mathrm{EM} 1321^{\mathrm{T}}$ exhibited catalase and oxidase activities. Physiological and biochemical properties were tested by using the API 20NE, API $50 \mathrm{CH}$, and API ZYM systems (BioMérieux). In the API ZYM system, enzyme activity was detected for alkaline phosphatase, esterase (C4), esterase lipase (C8), leucine arylamidase, acid phosphatase, naphthol-AS-BIphosphohydrolase, $\beta$-galactosidase, and valine arylamidase (Table 2). No activity was detected for lipase, trypsin, $\alpha$-chymotrypsin, $\alpha$-galactosidase, $\beta$-glucuronidase, $\alpha$-glucosidase, $N$-acetyl- $\beta$-glucosaminidase, cystine arylamidase, $\alpha$-mannosidase, and $\alpha$-fucosidase. In the API 20NE system, positive reactions were observed for nitrate reduction and negative reactions were observed for indole production, glucose fermentation, arginine dihydrolase, urease activity, and aesculin and gelatin hydrolysis. The strain assimilated $\mathrm{d}$-glucose and $\mathrm{l}$ arabinose, but not d-mannitol, d-mannose, d-maltose, potassium gluconate, $\mathrm{N}$-acetylglucosamine, capric acid, adipic acid, malic acid, trisodium citrate, or phenylacetic acid. Acid was produced from 1 -arabinose, d-xylose, $d-$ galactose, d-glucose, d-fructose, d-mannose, and dlactose (API 50CH).

Matrix-assisted laser-desorption/ionization time-offlight (MALDI-TOF) MS protein analysis was carried out as previously described [24]. Deposits were done from 12 isolated colonies for each strain (strain EM1321 ${ }^{\mathrm{T}}$ and reference strains). Measurements were 


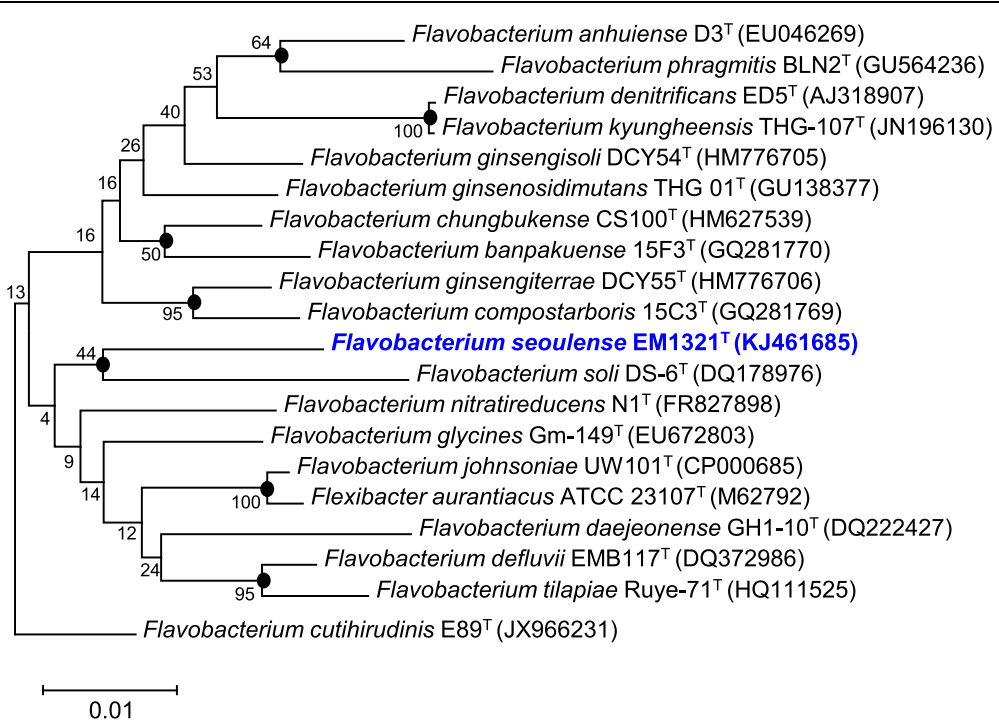

Figure 1 Phylogenetic tree highlighting the position of Flavobacterium seoulense EM $1321^{\top}$ relative to the type strains of other species within the genus Flavobacterium. The strains and their corresponding GenBank accession numbers of 16S rRNA genes are indicated in parentheses. The sequences were aligned using JPHYDIT and the phylogenetic inferences were obtained using neighbour-joining method with MEGA version 5 [13]. The numbers at nodes are the percentage of bootstrap values obtained by 1,000 replicates. Solid circles indicate that the corresponding nodes were also recovered in maximum-likelihood tree. Bar, 0.01 substitutions per nucleotide position.

made with a Microflex spectrometer (Bruker Daltonics, Leipzig, Germany). Spectra were recorded in the positive linear mode for the mass range of 2,000 to $20,000 \mathrm{Da}$ (parameter settings: ion source 1 (IS1), $20 \mathrm{kV}$; IS2, $18.5 \mathrm{kV}$; lens, $7 \mathrm{kV}$ ). The time of acquisition was between 30 seconds and 1 minute per spot. The twelve EM1321 ${ }^{\mathrm{T}}$ spectra were imported into the MALDI

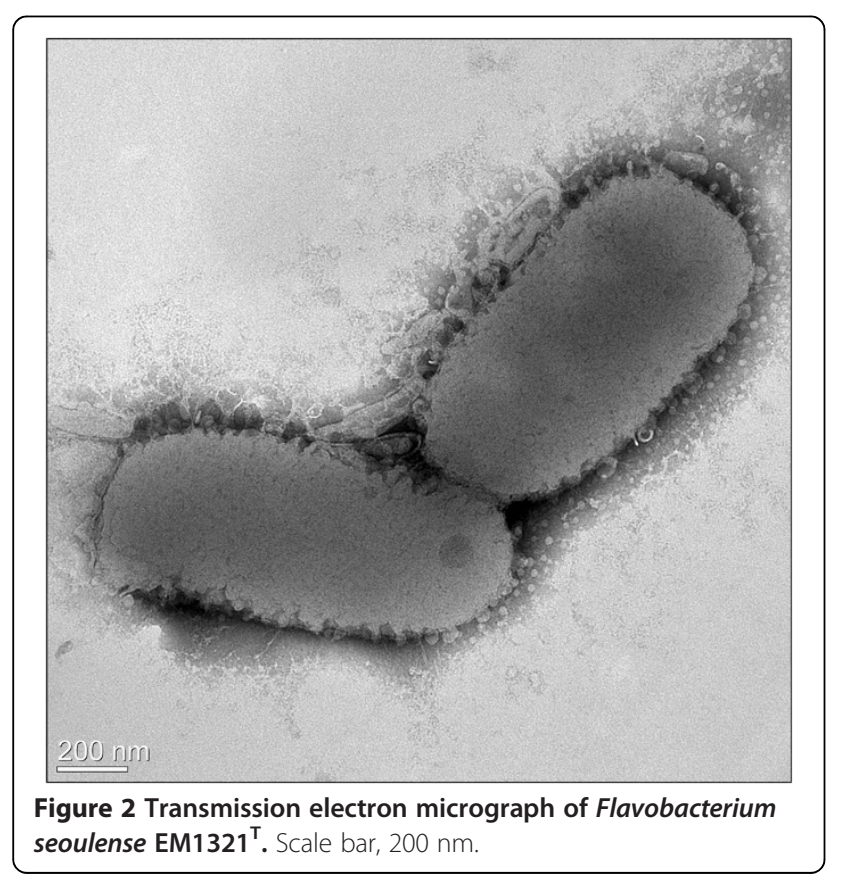

BioTyper software (version 2.0; Bruker) and analyzed by standard pattern matching (with default parameter settings) against 4,613 bacterial spectra including eight Flavobacterium species, used as reference data, in the BioTyper database. For strain $\mathrm{EM} 1321^{\mathrm{T}}$ spectrum (Figure 3), no significant score was obtained, suggesting that our isolate was not a member of the eight known species in the database. Spectrum differences with the two closely related Flavobacterium species are shown in Figure 4.

\section{Genome sequencing information}

Genome project history

Flavobacterium seoulense EM1321 ${ }^{\mathrm{T}}$ was selected for genome sequencing based on its phylogenetic position and its 16S rRNA similarity to other members of the genus Flavobacterium. The genome sequence was deposited in GenBank under accession number JNCA00000000.1. A summary of the project and the Minimum Information about a Genome Sequence (MIGS) [14] are shown in Table 3.

\section{Growth conditions and DNA isolation}

Flavobacterium seoulense EM $1321^{\mathrm{T}}$ was cultured aerobically on R2A agar medium at $30^{\circ} \mathrm{C}$. Genomic DNA was extracted using the QIAamp DNA mini kit (Qiagen).

\section{Genome sequencing and assembly}

The genome of strain EM1321 ${ }^{\mathrm{T}}$ was sequenced at ChunLab, Inc. by using an Illumina Miseq_PE_300 system 
Table 2 Phenotypic characteristics of Flavobacterium seoulense EM1321 ${ }^{\top}$ and phylogenetically related Flavobacterium species

\begin{tabular}{|c|c|c|c|}
\hline Characteristic & F. seoulense EM1321 ${ }^{\top}$ & F. soli KACC $17417^{\top}$ & F. nitratireducens JCM $17678^{\top}$ \\
\hline Cell length $(\mu \mathrm{m})$ & $1.0-1.5$ & $1.0-3.0^{\mathrm{a}}$ & $1.0-1.5^{b}$ \\
\hline Oxygen requirement & Aerobic & Aerobic $^{\mathrm{a}}$ & Aerobic $^{\mathrm{b}}$ \\
\hline Gram stain & - & $-^{a}$ & $-\mathrm{b}$ \\
\hline Salt requirement & $0-4 \%$ & $0-2 \%^{\mathrm{a}}$ & $0-1 \%^{\mathrm{b}}$ \\
\hline Motility & + & $t^{a}$ & $-\mathrm{b}$ \\
\hline Spore formation & - & - & - \\
\hline \multicolumn{4}{|l|}{ Production of } \\
\hline Alkaline phosphatase & + & + & + \\
\hline Acid phosphatase & + & + & + \\
\hline Catalase & + & + & + \\
\hline Oxidase & + & + & + \\
\hline Nitrate reductase & + & & + \\
\hline Urease & - & - & + \\
\hline$a$-Galactosidase & - & - & + \\
\hline$\beta$-Galactosidase & + & - & - \\
\hline$\beta$-Glucuronidase & - & - & - \\
\hline$a$-Glucosidase & - & - & + \\
\hline$\beta$-Glucosidase & - & $+^{*}$ & - \\
\hline$N$-Acetyl- $\beta$-glucosaminidase & - & - & + \\
\hline Indole & - & - & - \\
\hline Esterase & + & + & + \\
\hline Esterase lipase & + & + & + \\
\hline Naphthol-AS-BI-phosphohydrolase & + & + & + \\
\hline Leucine arylamidase & + & + & + \\
\hline Cystine arylamidase & - & - & + \\
\hline Valine arylamidase & + & $+^{*}$ & + \\
\hline \multicolumn{4}{|l|}{ Utilization of } \\
\hline d-glucose & + & $-^{*}$ & + \\
\hline I-arabinose & + & $-^{*}$ & - \\
\hline d-mannose & & $-^{*}$ & + \\
\hline d-mannitol & - & - & - \\
\hline $\mathrm{d}$-maltose & - & $-^{*}$ & + \\
\hline $\mathrm{G}+\mathrm{C}$ content $(\mathrm{mol} \%)$ & 33.25 & $36.9^{\mathrm{a}}$ & $36.3^{\mathrm{b}}$ \\
\hline Habitat & Freshwater & Soila ${ }^{a}$ & Seawater ${ }^{\mathrm{b}}$ \\
\hline
\end{tabular}

+: positive result, -: negative result.

${ }^{\mathrm{a} D a t a}$ from Yoon et al. [5].

${ }^{\mathrm{b}}$ Data from Nupur et al. [8].

*Data incongruent with a previous study [5].

with $2 \times 300$ paired-end reads. The Illumina platform provided $166 \times$ coverage (for a total of 3,792,640 sequencing reads) of the genome. CLC Genomics Workbench (ver. 6.5.1) was used for sequence assembly and quality assessment. The final draft assembly contained 56 contigs.

\section{Genome annotation}

The genes in the assembled genome were predicted with Rapid Annotation using Subsystem Technology (RAST) server databases [25] and the gene-caller GLIMMER 3.02 [26]. The predicted ORFs were annotated by searching clusters of orthologous groups (COGs) [11] using the 

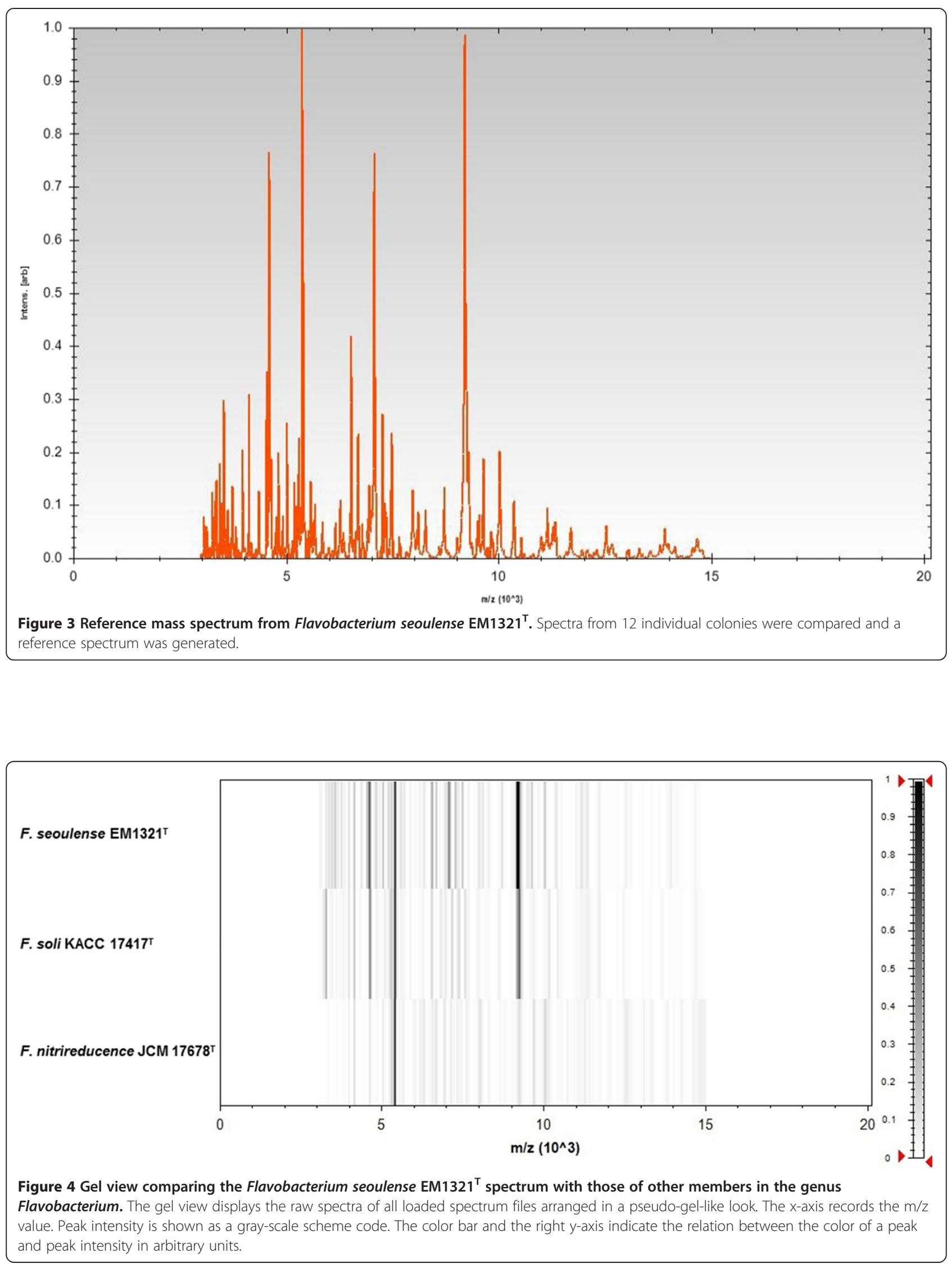
Table 3 Genome sequencing project information

\begin{tabular}{lll}
\hline MIGS ID & Property & Term \\
\hline MIGS-31 & Finishing quality & High-quality draft \\
MIGS-28 & Libraries used & One paired-end Illumina library \\
MIGS-29 & Sequencing platforms & Illumina MiSeq \\
MIGS-31.2 & Fold coverage & 166x \\
MIGS-30 & Assemblers & CLCbio CLC Genomics \\
& & Workbench, version 6.5.1 \\
MIGS-32 & Gene calling method & Glimmer 3.0 \\
& Genbank ID & JNCA00000000.1 \\
& Genbank Date of Release & 2014/05/27 \\
& BIOPROJECT & PRJNA248341 \\
& Project relevance & Environmental, Biotechnological \\
MIGS-13 & Source Material Identifier & KACC 18114, JCM 30145 \\
\hline
\end{tabular}

SEED database [27]. RNAmmer 1.2 [28] and tRNAscanSE 1.23 [29] were used to identify rRNA genes and tRNA genes, respectively. CRISPR repeats were examined using CRISPR recognition tool (CRT) [30]. CLgenomics ${ }^{\mathrm{Ts}} 1.06$ (ChunLab) was used to visualize the genomic features.

\section{Genome properties}

The genome comprised a circular chromosome with a length of 3,792,640 bp and 33.25\% G + C content (Figure 5 and Table 4). It is composed of 56 contigs. Of the 3,282 predicted genes, 3,230 were protein-coding genes and 52

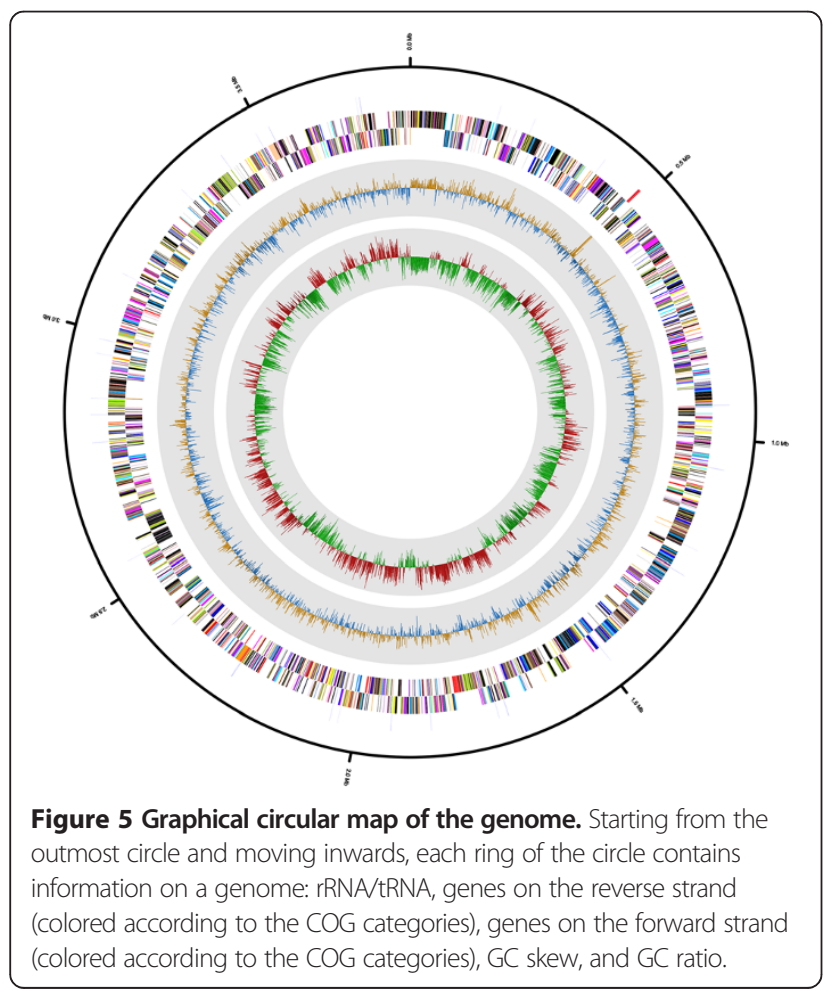

Table 4 Genome statistics

\begin{tabular}{|c|c|c|}
\hline Attribute & Value & $\%$ of total ${ }^{\mathrm{a}}$ \\
\hline Genome size (bp) & $3,792,640$ & 100 \\
\hline DNA coding region (bp) & $3,386,688$ & 89.30 \\
\hline $\mathrm{G}+\mathrm{C}$ content $(\mathrm{bp})$ & $1,261,070$ & 33.25 \\
\hline Total genes & 3,282 & 100 \\
\hline RNA genes & 52 & 1.58 \\
\hline rRNA operons & 4 & \\
\hline Protein-coding genes & 3,230 & 98.42 \\
\hline Pseudo genes & 45 & 1.37 \\
\hline Genes with function prediction & 2,054 & 62.58 \\
\hline Genes assigned to COGs & 2,281 & 69.50 \\
\hline Genes assigned Pfam domains & 1,997 & 60.85 \\
\hline Genes with signal peptides & 119 & 3.63 \\
\hline Genes with transmembrane helices & 682 & 20.78 \\
\hline CRISPR repeats & 0 & \\
\hline
\end{tabular}

${ }^{a}$ The total is based on either the size of the genome in base pairs or the total number of protein-coding genes in the annotated genome.

were RNA genes (2 rRNA genes and 50 tRNA genes). The sequencing coverage of rRNA operon $(673 \times)$ indicated that 4 copies of rRNA operons are exist in this genome. The majority of the protein-coding genes (2,054 genes, $62.58 \%$ ) were assigned putative functions, while the remaining genes were annotated as hypothetical proteins (1,176 genes, $35.83 \%)$. The properties of and statistics for the genome are summarized in Table 4. The distribution of genes into COG functional categories is presented in Table 5 and Figure 5.

\section{Conclusions}

Based on the results from phylogenetic and phenotypic analyses, we formally propose the creation of the new species Flavobacterium seoulense sp. nov. for strain EM1321 ${ }^{\mathrm{T}}$. The non-contiguous genome sequence of the type strain was determined and described here.

\section{Description of Flavobacterium seoulense sp. nov.}

Flavobacterium seoulense (seo.ul.en'se. N.L. neut. adj., named after Seoul, Korea, the geographical origin of the type strain).

Aerobic, Gram-reaction negative. Cells are rod shaped and motile by gliding. Does not have a flagellum. The colonies are yellow in color and translucent on R2A agar medium. Grows at $4-35^{\circ} \mathrm{C}$, with optimum growth at $30^{\circ} \mathrm{C}$ and in $0-4 \%(\mathrm{w} / \mathrm{v}) \mathrm{NaCl}$. Catalase- and oxidase-positive. Positive for alkaline phosphatase, esterase (C4), esterase lipase (C8), leucine arylamidase, acid phosphatase, naphthol-AS-BI-phosphohydrolase, $\beta$-galactosidase, and valine arylamidase. Positive for nitrate reduction, but negative for indole production, glucose fermentation, arginine dihydrolase, urease activity, and aesculin and gelatin 
Table 5 Number of genes associated with the $\mathbf{2 5}$ general COG functional categories

\begin{tabular}{|c|c|c|c|}
\hline Code & Value & $\%^{\mathrm{a}}$ & Description \\
\hline J & 157 & 4.86 & Translation \\
\hline A & 1 & 0.03 & RNA processing and modification \\
\hline K & 148 & 4.58 & Transcription \\
\hline L & 123 & 3.81 & Replication, recombination, and repair \\
\hline B & 0 & 0.00 & Chromatin structure and dynamics \\
\hline D & 23 & 0.71 & Cell cycle control, mitosis, and meiosis \\
\hline Y & 0 & 0.00 & Nuclear structure \\
\hline V & 40 & 1.24 & Defense mechanisms \\
\hline $\mathrm{T}$ & 121 & 3.75 & Signal transduction mechanisms \\
\hline M & 220 & 6.81 & Cell wall/membrane biogenesis \\
\hline N & 18 & 0.56 & Cell motility \\
\hline Z & 0 & 0.00 & Cytoskeleton \\
\hline W & 0 & 0.00 & Extracellular structures \\
\hline$U$ & 45 & 1.39 & Intracellular trafficking and secretion \\
\hline $\mathrm{O}$ & 81 & 2.51 & $\begin{array}{l}\text { Posttranslational modification, protein } \\
\text { turnover, and chaperones }\end{array}$ \\
\hline C & 122 & 3.78 & Energy production and conversion \\
\hline G & 207 & 6.41 & Carbohydrate transport and metabolism \\
\hline E & 170 & 5.26 & Amino acid transport and metabolism \\
\hline $\mathrm{F}$ & 62 & 1.92 & Nucleotide transport and metabolism \\
\hline $\mathrm{H}$ & 127 & 3.93 & Coenzyme transport and metabolism \\
\hline I & 93 & 2.88 & Lipid transport and metabolism \\
\hline$P$ & 170 & 5.26 & Inorganic ion transport and metabolism \\
\hline Q & 42 & 1.30 & $\begin{array}{l}\text { Secondary metabolites biosynthesis, } \\
\text { transport, and catabolism }\end{array}$ \\
\hline R & 318 & 9.85 & General function prediction only \\
\hline S & 196 & 6.07 & Function unknown \\
\hline - & 949 & 29.38 & Not in COGs \\
\hline
\end{tabular}

${ }^{a}$ The total is based on the total number of protein coding genes in the annotated genome.

hydrolysis. Negative for lipase, trypsin, $\alpha$-chymotrypsin, $\alpha$ galactosidase, $\beta$-glucuronidase, $\alpha$-glucosidase, $\beta$-glucosidase, $N$-acetyl $-\beta$-glucosaminidase, or cystine arylamidase activity. This strain assimilated d-glucose and l-arabinose, but not d-mannitol, d-mannose, d-maltose, $\mathrm{N}$-acetylglucosamine, potassium gluconate, capric acid, adipic acid, malic acid, trisodium citrate, or phenylacetic acid. Produces acid from l-arabinose, d-xylose, d-galactose, dglucose, $d$-fructose, $d$-mannose, and d-lactose.

The $G+C$ content of the genome is $33.25 \%$. The $16 \mathrm{~S}$ rRNA and genome sequences are deposited in GenBank under accession numbers KJ461685 and JNCA00000000.1, respectively. The type strain EM1321 ${ }^{\mathrm{T}}\left(=\mathrm{KACC} 18114^{\mathrm{T}}=\right.$ JCM $30145^{\mathrm{T}}$ ) was isolated from stream water in Bukhansan National Park, Seoul, Korea.
Competing interests

The authors declare that they have no competing interests.

\section{Authors' contributions}

SS drafted the manuscript, performed laboratory experiments, and analyzed the data. HG cultured samples and performed the electron micrograph and phylogenetic analysis. YC, SK and DY sequenced, assembled, and annotated the genome. HY organized the study and drafted the manuscript. All authors read and approved the final manuscript.

\section{Acknowledgements}

This work was supported by the Basic Science Research Programs through the National Research Foundation of Korea (NRF) funded by the Ministry of Science, ICT, and Future Planning (NRF-2013R1A1A3010041) and supported by a Korea University Grant.

\section{Author details}

'Department of Public Health Sciences, BK21PLUS Program in Embodiment: Health-Society Interaction, Graduate School, Korea University, Seoul, Republic of Korea. ${ }^{2}$ School of Biosystem and Biomedical Science, Korea University, Seoul, Republic of Korea. ${ }^{3}$ Chunlab, Inc., Seoul, Republic of Korea. ${ }^{4}$ Department of Laboratory Medicine and Research Institute of Bacterial Resistance, Yonsei University College of Medicine, Seoul, Republic of Korea. ${ }^{5}$ Korea University Guro Hospital, Korea University, Seoul, Republic of Korea.

Received: 8 July 2014 Accepted: 24 November 2014

Published: 29 December 2014

\section{References}

1. Bergey DH, Harrison FC, Breed RS WHB, Huntoon FM. Bergey's Manual of Determinative Bacteriology, Volume 4. 1st ed. Baltimore: The Williams and Wilkins Co; 1923: p. 1-442.

2. Skerman VBD, Mcgowan V, Sneath PHA. Approved lists of bacterial names. Int J Syst Bacteriol. 1980; 30:225-420.

3. Bernardet JF, Segers P, Vancanneyt M, Berthe F, Kersters K, Vandamme P. Cutting a gordian knot: Emended classification and description of the genus Flavobacterium, emended description of the family Flavobacteriaceae, and proposal of Flavobacterium hydatis nom nov (basonym, Cytophaga aquatilis Strohl and Tait 1978). Int J Syst Bacteriol. 1996; 46:128-48.

4. Kim BY, Weon HY, Cousin S, Yoo SH, Kwon SW, Go SJ, Stackebrandt E. Flavobacterium daejeonense sp. nov. and Flavobacterium suncheonense sp. nov., isolated from greenhouse soils in Korea. Int J Syst Evol Microbiol. 2006; 56:1645-49.

5. Yoon JH, Kang SJ, Oh TK. Flavobacterium soli sp nov., isolated from soil. Int J Syst Evol Microbiol. 2006; 56:997-1000.

6. Tamaki H, Hanada S, Kamagata Y, Nakamura K, Nomura N, Nakano K, Matsumura M. Flavobacterium limicola sp. nov., a psychrophilic, organic-polymer-degrading bacterium isolated from freshwater sediments. Int J Syst Evol Microbiol. 2003; 53:519-26.

7. Kim JH, Kim KY, Cha CJ. Flavobacterium chungangense sp. nov., isolated from a freshwater lake. Int J Syst Evol Microbiol. 2009; 59:1754-58.

8. Nupur Bhumika V, Srinivas TN, Kumar PA. Flavobacterium nitratireducens sp. nov., an amylolytic bacterium of the family Flavobacteriaceae isolated from coastal surface seawater. Int J Syst Evol Microbiol. 2013; 63:2490-96.

9. NamesforLife, LLC. http://doi.namesforlife.com/10.1601/tx.8071.

10. Kim OS, Cho YJ, Lee K, Yoon SH, Kim M, Na H, Park SC, Jeon YS, Lee JH, Yi H, Won S, Chun J. Introducing EzTaxon-e: a prokaryotic 16S rRNA gene sequence database with phylotypes that represent uncultured species. Int J Syst Evol Microbiol. 2012; 62:716-21.

11. Stackebrandt E, Ebers J. Taxonomic parameters revisited: tarnished gold standards. Microbiol Today. 2006; 33:152-55.

12. Jeon YS, Chung H, Park S, Hur I, Lee JH, Chun J. jPHYDIT: a JAVA-based integrated environment for molecular phylogeny of ribosomal RNA sequences. Bioinformatics. 2005; 21:3171-713.

13. Tamura K, Peterson D, Peterson N, Stecher G, Nei M, Kumar S. MEGA5: molecular evolutionary genetics analysis using maximum likelihood, evolutionary distance, and maximum parsimony methods. Mol Biol Evol. $2011 ; 28: 2731-39$.

14. Field D, Garrity G, Gray T, Morrison N, Selengut J, Sterk P, Tatusova T, Thomson N, Allen MJ, Angiuoli SV, Ashburner M, Axelrod N, Baldauf S, 
Ballard S, Boore J, Cochrane G, Cole J, Dawyndt P, De Vos P, dePamphilis C, Edwards R, Faruque N, Feldman R, Gilbert J, Gilna P, Glockner FO, Goldstein $P$, Guralnick R, Haft D, Hancock D, et al. The minimum information about a genome sequence (MIGS) specification. Nat Biotechnol. 2008; 26:541-47.

15. Woese CR, Kandler O, Wheelis ML. Towards a natural system of organisms: proposal for the domains Archaea, Bacteria, and Eucarya. Proc Natl Acad Sci USA. 1990; 87:4576-79.

16. Krieg NR, Ludwig W, Euzéby J, Whitman WB, Phylum XIV. Bacteroidetes phyl. nov. In: Krieg NR, Staley JT, Brown DR, Hedlund BP, Paster BJ, Ward NL, Ludwig W, Whitman WB, editors. Bergey's Manual of Systematic Bacteriology, Volume 4. 2nd ed. New York: Springer; 2011: p. 25.

17. Euzéby JP. Validation List No. 143. List of new names and new combinations previously effectively, but not validly, published. Int I Syst Evol Microbiol. 2012; 62:1-4

18. Bernardet JF, Order I. Flavobacteriales ord. nov. In: Krieg NR, Staley JT, Brown DR, Hedlund BP, Paste RBJ, Ward NL, Ludwig W, Whitman WB, editors. Bergey's Manual of Systematic Bacteriology, Volume 4. 2nd ed. New York: Springer; 2011: p. 105

19. Bernardet JF, Family I. Flavobacteriaceae. In: Krieg NR, Staley JT, Brown DR, Hedlund BP, Paste RBJ, Ward NL, Ludwig W, Whitman WB, editors. Bergey's Manual of Systematic Bacteriology, Volume 4. 2nd ed. New York: Springer; 2011: p. 106-11.

20. Bernardet JF, Nakagawa Y, Holmes B. Proposed minimal standards for describing new taxa of the family Flavobacteriaceae and emended description of the family. Int I Syst Evol Microbiol. 2002; 52:1049-70.

21. List Editor. Validation List No. 41. Validation of publication of new names and new combinations previously effectively published outside the IJSEM. Int J Syst Bacteriol. 1992; 42:327-28.

22. Holmes B, Owen RJ. Proposal that Flavobacterium breve be substituted as the type species of the genus in place of Flavobacterium aquatile and emended description of the genus Flavobacterium: status of the named species of Flavobacterium. Request for an Opinion. Int I Syst Bacteriol. 1979: 29:416-26.

23. Ashburner M, Ball CA, Blake JA, Botstein D, Butler H, Cherry JM, Davis AP, Dolinski K, Dwight SS, Eppig JT, Harris MA, Hill DP, Issel-Tarver L, Kasarskis A, Lewis S, Matese JC, Richardson JE, Ringwald M, Rubin GM, Sherlock G. Gene ontology: tool for the unification of biology. The Gene Ontology Consortium. Nat Genet. 2000; 25:25-9.

24. Seng P, Drancourt M, Gouriet F, La Scola B, Fournier PE, Rolain JM, Raoult D. Ongoing revolution in bacteriology: routine identification of bacteria by matrix-assisted laser desorption ionization time-of-flight mass spectrometry. Clin Infect Dis. 2009; 49:543-51.

25. Aziz RK, Bartels D, Best AA, DeJongh M, Disz T, Edwards RA, Formsma K, Gerdes S, Glass EM, Kubal M, Meyer F, Olsen GJ, Olson R, Osterman AL, Overbeek RA, McNeil LK, Paarmann D, Paczian T, Parrello B, Pusch GD, Reich C, Stevens R, Vassieva O, Vonstein $V$, Wilke A, Zagnitko O. The RAST Server: rapid annotations using subsystems technology. BMC Genomics. 2008; 9:75.

26. Delcher AL, Bratke KA, Powers EC, Salzberg SL. Identifying bacterial genes and endosymbiont DNA with Glimmer. Bioinformatics. 2007; 23:673-79.

27. Overbeek R, Begley T, Butler RM, Choudhuri JV, Chuang HY, Cohoon M, de Crecy-Lagard V, Diaz N, Disz T, Edwards R, Fonstein M, Frank ED, Gerdes S, Glass EM, Goesmann A, Hanson A, Iwata-Reuyl D, Jensen R, Jamshidi N, Krause L, Kubal M, Larsen N, Linke B, McHardy AC, Meyer F, Neuweger H, Olsen G, Olson R, Osterman A, Portnoy V, et al. The subsystems approach to genome annotation and its use in the project to annotate 1000 genomes. Nucleic Acids Res. 2005; 33:5691-702.

28. Lagesen $\mathrm{K}$, Hallin $\mathrm{P}$, Rodland EA, Staerfeldt HH, Rognes T, Ussery DW. RNAmmer: consistent and rapid annotation of ribosomal RNA genes. Nucleic Acids Res. 2007; 35:3100-08.

29. Lowe TM, Eddy SR. tRNAscan-SE: a program for improved detection of transfer RNA genes in genomic sequence. Nucleic Acids Res. 1997; 25:955-64.

30. Bland C, Ramsey TL, Sabree F, Lowe M, Brown K, Kyrpides NC, Hugenholtz P. CRISPR recognition tool (CRT): a tool for automatic detection of clustered regularly interspaced palindromic repeats. BMC Bioinformatics. 2007; 8:209.

doi:10.1186/1944-3277-9-34

Cite this article as: Shin et al: Non-contiguous finished genome sequence and description of the gliding bacterium Flavobacterium seoulense sp. nov.. Standards in Genomic Sciences 2014 9:34.

\section{Submit your next manuscript to BioMed Central and take full advantage of:}

- Convenient online submission

- Thorough peer review

- No space constraints or color figure charges

- Immediate publication on acceptance

- Inclusion in PubMed, CAS, Scopus and Google Scholar

- Research which is freely available for redistribution 